\title{
Comparative analysis of superabsorbent properties of PVP and PAA nanofibres
}

DOI: $10.35530 / I T .072 .04 .1806$

\section{ABSTRACT - REZUMAT \\ Comparative analysis of superabsorbent properties of PVP and PAA nanofibres}

This study presents the comparative analysis of production, characterization and absorption properties of Polyvinylpyrrolidone (PVP) and Polyacrylic acid (PAA) nanofibres. Firstly, optimization studies about polymer (PVP and $P A A)$, superabsorbent additive (waterlock)(WL) and crosslinker agent (sodium persulfate and glutaraldehyde) concentrations were achieved. Then solution properties such as conductivity, surface tension and viscosity were determined. Electrospinning was carried out under the optimum process parameters (voltage, distance between the electrodes, solution feed rate etc.) to obtain superabsorbent nanofibrous surfaces. Surface and fibre morphologies were analysed with Scanning Electron Microscopy (SEM) and thickness of nanoweb and weight in grams of nanofibres were also measured. Lastly, optimized PVP and PAA nanofibres were compared in terms of absorption properties with water and synthetic urine with various times from 5 to 86400 seconds. According to the results, generally fine, smooth and uniform nanofibres were obtained. It was observed that the solution viscosity, conductivity, and average fibre diameter increase with waterlock (WL) and cross-linker additions while surface tension was not change. In addition, PAA nanofibres' absorption capacity with water and synthetic urine was higher than PVP nanofibres, while PVP nanofibres' absorption rate is higher. It is possible to say that electrospun nanofibrous surfaces that are ultra-thin, light, porous and with high specific surface area to volume ratio are promising for new superabsorbent materials.

Keywords: polyvinylpyrrolidone, polyacrylic acid, electrospinning, nanofibres, superabsorbent

\section{Analiza comparativă a proprietăților superabsorbante ale nanofibrelor de PVP și de PAA}

Acest studiu prezintă analiza comparativă a proprietăților de absorbție a nanofibrelor de polivinilpirolidonă (PVP) și de acid poliacrilic (PAA). În primul rând, s-au realizat studii de optimizare cu privire la concentrațiile de polimer (PVP și $P A A)$, aditiv superabsorbant (blocaj de apă) (WL) și agent de reticulare (persulfat de sodiu și glutaraldehidă). Apoi au fost determinate proprietățile soluției, cum ar fi conductivitatea, tensiunea superficială și viscozitatea. Electrofilarea fost efectuată sub parametrii optimi de proces (tensiune, distanță între electrozi, viteza de alimentare a soluției etc.), pentru a obtine suprafete de nanofibre superabsorbante. Suprafața și morfologiile fibrelor au fost analizate prin microscopie electronică cu scanare (SEM) și au fost determinate grosimea nanomaterialului și greutatea în grame de nanofibre. În cele din urmă, nanofibrele de PVP și de PAA optimizate au fost comparate în ceea ce privește proprietățile de absorbție a apei și urinei sintetice, cu diferite perioade de la 5 la 86400 de secunde. Conform rezultatelor, în general s-au obținut nanofibre fine, netede și uniforme. S-a observat că viscozitatea, conductivitatea soluției și diametrul mediu al fibrelor cresc odată cu blocarea apei (WL) și adaugarea agenților de reticulare, în timp ce tensiunea superficială nu a fost modificată. În plus, capacitatea de absorbție a nanofibrelor de PAA, în ceea ce privește apa și urina sintetică a fost mai ridicată decât cea a nanofibrelor de PVP, în timp ce rata de absorbție a nanofibrelor de PVP este mai ridicată. Este posibil să se concluzioneze că suprafețele nanofibrelor electrofilate ultra-subțiri, ușoare, poroase și cu un raport suprafață - volum specific ridicat sunt promițătoare pentru noile materiale superabsorbante.

Cuvinte-cheie: polivinilpirolidonă, acid poliacrilic, electrofilare, nanofibre, superabsorbant

\section{INTRODUCTION}

Superabsorbent materials have high liquid absorption capability that has biocompatibility provide specific functionality for biomedical, wound dressing, agriculture, horticulture, drug release, waste water treatment and hygienic products for instance disposable diapers and sanitary napkins [1-4]. It is possible to produce textile surface using superabsorbent polymers (SAPs) (PVP, PAA, polyurethane, cellulose acetate, carboxymethylcellulose etc.) and additives (waterlock) (WL) with various methods [5]. Electrospinning is an effective method to produce ultra-thin and light superabsorbent nanofibrous surfaces that has high porosity, small pore size, small fibre diameter, high loading capacity, and high specific surface area to volume ratio [6-8].

In this study, PVP and PAA polymers were used as the polymers to produce superabsorbent nanofibrous surfaces with electrospinning. PVP is a Food and Drug Administration (FDA) approved water-soluble polymer with excellent biocompatibility and high capacity of liquid absorption up to $40 \%$ of its own weight $[9,10]$. Polyacrylic acid is also well known superabsorbent and $\mathrm{pH}$ sensitive polymer that forms hydrogels with a swelling behaviour depending on its 
easily ionisable carboxyl groups [11]. All these properties play vital roles in hygienic textiles and biocompatible materials, that's why these were chosen as the raw materials for this research. In literature, there are some studies about superabsorbent nanofibres production and characterization. In 2005, Li and Hsieh studied PAA and polyvinyl(alcohol) (PVA) nanofibre production and they determined that nanofibrous material absorbed liquid up to 31 times of its weight [12]. In the other study, Hansen et al. produced polyurethane nanofibres with waterlock superabsorbent additive and observed that nanofibre-based surfaces reached $400-5000 \%$ of absorption capacity in water, while it reached $500-1250 \%$ of absorption capacity in synthetic urine [13]. In addition, Martinova and Lubasova, developed superabsorbent electrospun material by needle electrospinning method using PAA polymer and compared with commercial superabsorbent fibres. They determined that nanofibrous material has higher absorption rate than commercial superabsorbent fibres due to superior properties of nanofibres [1]. In addition, Lubasova et al. studied about PVP and PAA mixture of nanofibre production with dimethylformamide (DMF) solvent and investigated swelling capacity of both nanofibrous surfaces. They observed that PVP and PAA blend nanofibres reached higher absorption capacity than from pure PVP nanofibres [9]. On the other hand, in the last studies, one research team from Iran studied about PAA superabsorbent nanofibres and characterizations with different electrospinning principles such as needleless and gas-assisted electrospinning [14, 15]. Furthermore, there is no study about comparative analysis of absorption properties of cross-linked PVP and PAA nanofibres with superabsorbent additive (waterlock) in literature. For this reason, the focus was on this subject in the paper.

\section{EXPERIMENTAL}

\section{Materials}

In this study, PVP (Mw 360.000, Sigma Aldrich) and PAA (Mw 450.000, Sigma Aldrich) were used as the polymers, ethanol (Merck Millipore) was used as a solvent, waterlock (Veskim Chemistry) was used as a superabsorbent additive, glutaraldehyde (GA) (Sigma Aldrich) and sodium persulfate (SP) (Sigma Aldrich) were used as the cross-linker agents.

\section{Method}

Firstly, PVP/ethanol and PAA/ethanol solutions were prepared under the same conditions by magnetic stirring at room temperature for two hours. The PVP and PAA polymer concentrations were used as $10 \mathrm{wt} \%$ and 5 wt $\%$ respectively. WL was then added to the prepared PVP and PAA polymer solutions at $15 \mathrm{wt} \%$ concentration. WL concentration was determined from the optimization studies in terms of fibre morphology and spinning performance. Finally, the cross-linkers (GA and SP) were added to the PVP and PAA polymer solutions and electrospun under the same process parameters. The concentration of
GA and SP were used 3 wt \% for both polymer solutions. Cross-linker concentration was also chosen from our preliminary studies. Polymer sample codes and contents were given as table 1.

Table 1

SAMPLE CODES AND CONTENTS OF PVP AND PAA
POLYMER SOLUTIONS

\begin{tabular}{|c|c|c|c|}
\hline $\begin{array}{c}\text { Sample } \\
\text { code }\end{array}$ & $\begin{array}{c}\text { Polymer } \\
\text { concentration } \\
\text { (wt \%) }\end{array}$ & $\begin{array}{c}\text { WL } \\
\text { concentration } \\
\text { (wt \%) }\end{array}$ & $\begin{array}{c}\text { Cross-linker } \\
\text { concentration } \\
\text { (wt \%) }\end{array}$ \\
\hline PVP01 & 10 & 0 & 0 \\
\hline PVP02 & 10 & 15 & 0 \\
\hline PVP03 & 10 & 15 & 3 \\
\hline PAA01 & 5 & 0 & 0 \\
\hline PAA02 & 5 & 15 & 0 \\
\hline PAA03 & 5 & 15 & 3 \\
\hline
\end{tabular}

In this study, solution properties (conductivity, viscosity, surface tension) of all polymer solutions prepared under the same conditions were determined. As it is known from the literature, solution properties have great importance in terms of both electrospinning performance and fibre morphology [16]. Selecta CD-2005 conductivity meter was used for conductivity measurements, Lamy Rheology (B-one Touch) viscometer was used for viscosity measurements under $5 \mathrm{~s}^{-1}$ shear rate and Biolin Scientific Attension was used to determine surface tension by Wilhelmy Plate Method. Afterwards, electrospinning was achieved under the same process parameters (table 2 ). All nanofibres were produced for half an hour and were collected on aluminium foil.

Table 2

\begin{tabular}{|c|c|c|c|c|c|}
\hline \multicolumn{5}{|c|}{ PROCESS PARAMETERS OF ELECTROSPINNING } \\
\hline $\begin{array}{c}\text { Voltage } \\
(\mathbf{k V})\end{array}$ & $\begin{array}{c}\text { Distance } \\
\text { between } \\
\text { elec- } \\
\text { trodes } \\
(\mathbf{c m})\end{array}$ & $\begin{array}{c}\text { Feed } \\
\text { rate } \\
(\mathbf{m l} / \mathrm{h})\end{array}$ & $\begin{array}{c}\text { Needle } \\
\text { diameter } \\
(\mathbf{m m})\end{array}$ & $\begin{array}{c}\text { Ambient } \\
\text { humidity } \\
(\%)\end{array}$ & $\begin{array}{c}\text { Ambient } \\
\text { temp. } \\
\left({ }^{\circ} \mathrm{C}\right)\end{array}$ \\
\hline 26.4 & 16.5 & 0.8 & 0.8 & $30 \pm 2$ & $22 \pm 2$ \\
\hline
\end{tabular}

Surface morphology of superabsorbent nanofibre membranes was analysed with SEM (FEI Quanta 250 FEG). One hundred of different measurements were taken from each SEM image, and then the average and weight average values were calculated to determine the fibre diameter uniformity coefficient. The method used to calculate the fibre diameter uniformity coefficient is based on the molar mass distribution in chemistry [17].

The number and weight average values were calculated by using the following equations:

$$
A_{n}=\frac{\sum n_{i} d_{i}}{\sum n_{i}} \quad \text { (average number) }
$$




$$
A_{w}=\frac{\sum n_{i} d_{i}^{2}}{\sum n_{i} d_{i}} \quad \text { (average weight) }
$$

where $d_{i}$ is fibre diameter, $n_{i}-$ the number of fibres. The fibre diameter uniformity coefficient was determined by the ratio of $A w / A n$ and the optimum value should be close to 1 to obtain uniform nanofibres [17].

Thickness measurement of nanofibrous web was carried out with Mitutoyo digital micrometer with an accuracy of $0.01 \mathrm{~mm}$. Weight in grams of nanofibres measurements were achieved using $2 \times 2$ dimensions of nanowebs.

Maximum absorption capacity of PVP and PAA nanofibres was determined with the method which was defined by Hansen et al. in literature [13]. The absorption test was carried out with water and synthetic urine for $5,10,60,300,600,1800,86400(24$ hours) seconds. Before the absorption tests, PVP and PAA nanofibre surfaces were cross-linked by fixing in an oven at $90^{\circ} \mathrm{C}$ for 3 hours and $97^{\circ} \mathrm{C}$ for 4 hours, respectively.

Firstly, dry weight of the nanofibre sample was weighed. After nanoweb was immersed in the beaker containing water and synthetic urine for 5 seconds and then excess water on the nanoweb surface was removed and wet weight of nanoweb was weighed again. This process was repeated by dipping the sample at different times to determine the absorption rate. $25 \mathrm{~g}$ of urea, $9 \mathrm{~g}$ of sodium chloride, $2.5 \mathrm{~g}$ of sodium phosphate, $3 \mathrm{~g}$ of ammonium chloride and 3 $\mathrm{g}$ of sodium sulphite were used for the preparation of synthetic urine. All materials were mixed with distilled water until the total volume was completed to $1 \mathrm{I}$ and dissolved in distilled water [13]. Absorption is defined as given in equation 3 [13]:

$$
Q=\left(W_{2}-W_{1}\right) / W_{1}
$$

where $Q$ is absorption, $W_{1}$ - initial weight and $W_{2}-$ wet weight.

\section{RESULTS AND DISCUSSION}

Firstly, solution properties such as: conductivity, viscosity and surface tension were determined. The results showed that conductivity and viscosity increased while surface tension was not related with the addition of WL and cross-linkers for both PVP and PAA (figure 1). In addition, PVP and PAA solutions surface tension results are very close to each other. In literature, it has been also reported that the crosslinker causes increasement in solution viscosity and conductivity [16]. Therefore, it is possible to say that results obtained from this study are compatible with literature.

SEM images and fibre diameter histograms of electrospun nanofibres produced with PVP and PAA polymers are given in figures 2 and 3 . It is possible to say that, in general, fine and uniform (bead free) nanofibres were produced and unimodal histogram curves were obtained except PVP01.

It is clearly evident from figure 4 that average fibre diameter increases with WL and cross-linker addition for both PVP and PAA. As it is well known from the literature, there is a strong relation between solution viscosity and fibre diameter [17]. The range of average fibre diameter obtained from this study is between in 345-506 $\mathrm{nm}$. The average fibre diameter of pure PVP nanofibres was measured as $353.56 \mathrm{~nm}$ and increased to $431.07 \mathrm{~nm}$ with WL and $491.98 \mathrm{~nm}$
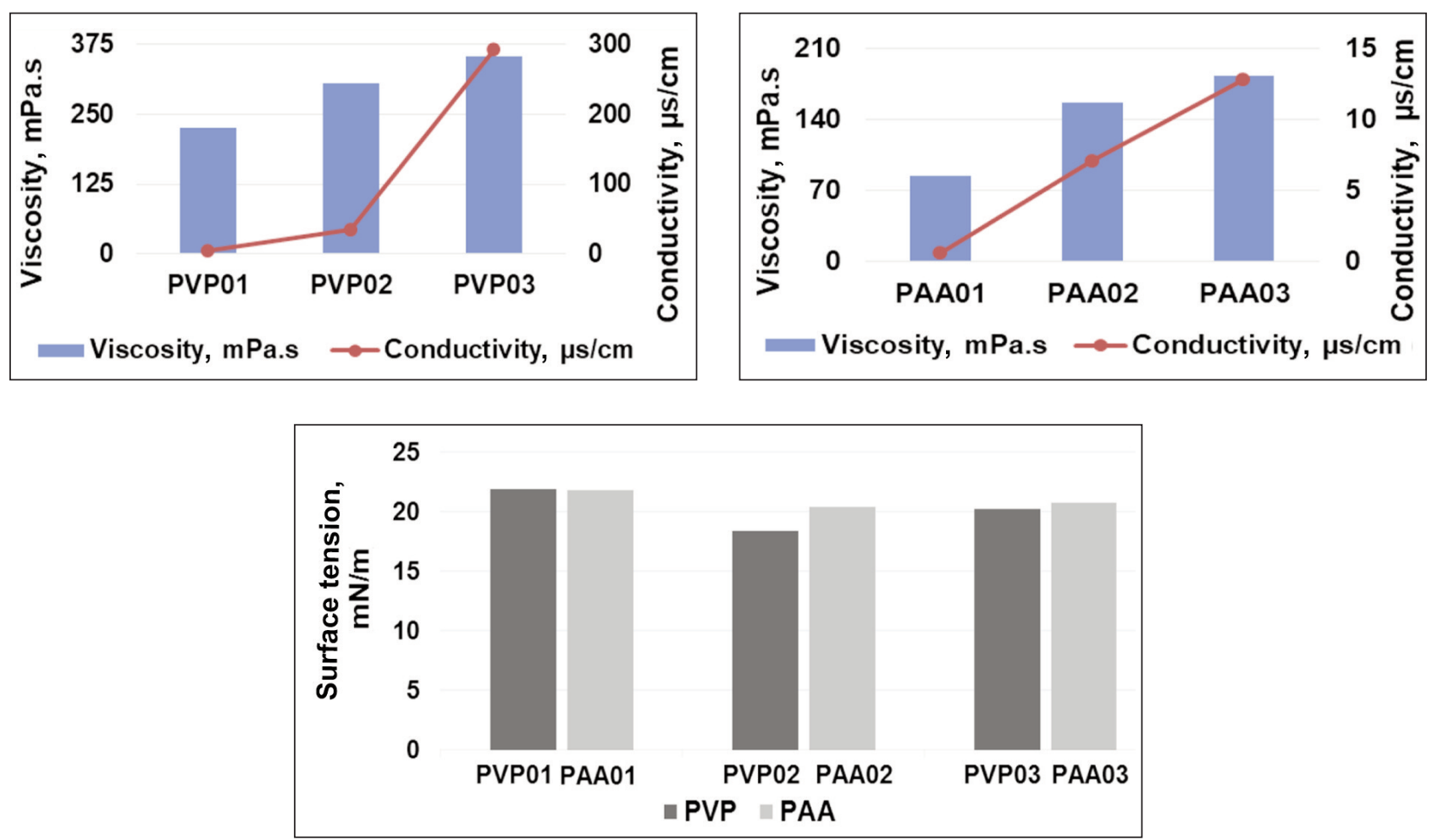

Fig. 1. Solution properties (conductivity, viscosity and surface tension) of PVP and PAA 


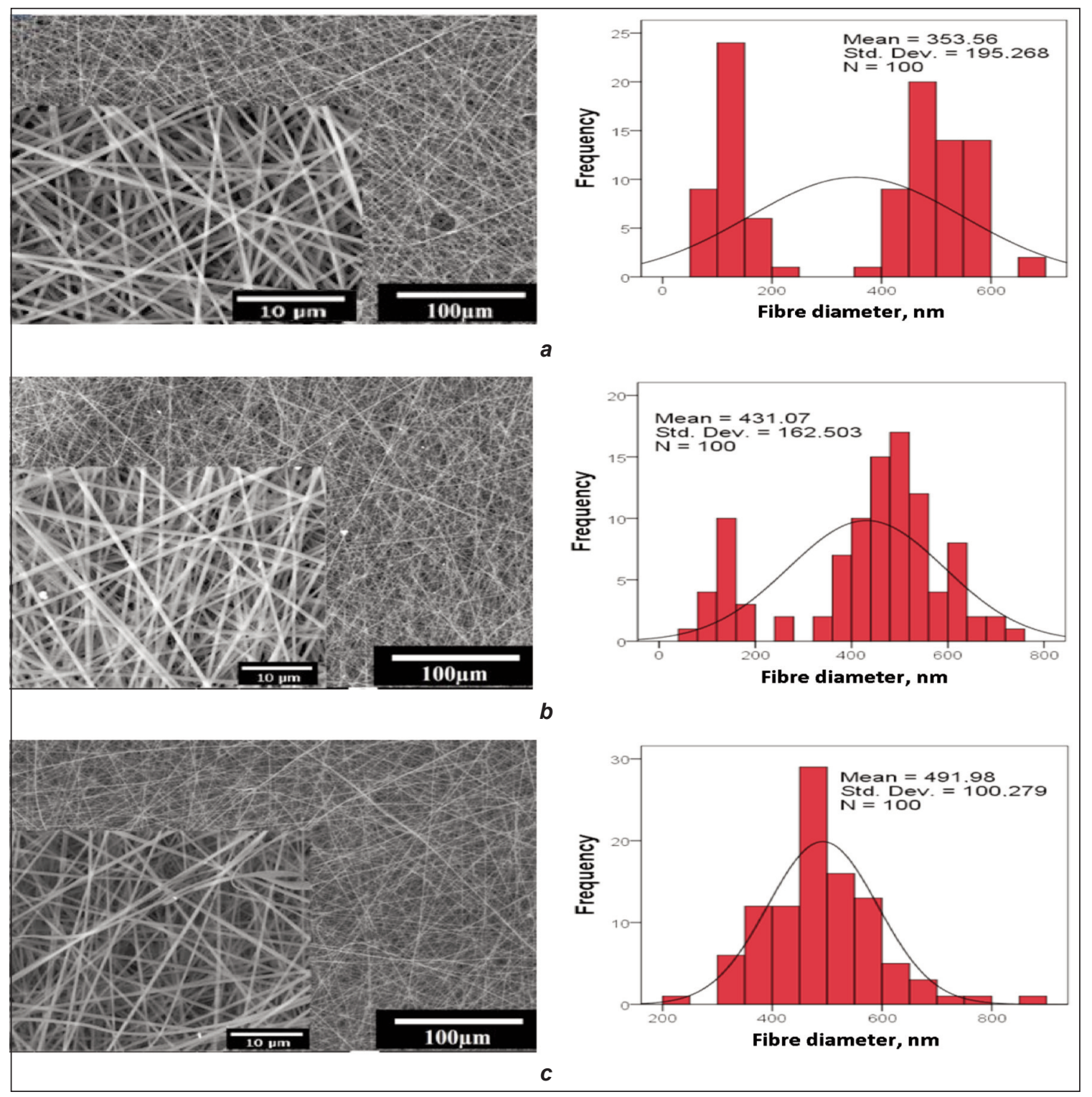

Fig. 2. SEM images $(1.000 x-10.000 x)$ and histograms of PVP nanofibre samples: $a$ - PVP01; $b$ - PVP02; $c$ - PVP03

with sodium persulfate addition. The most uniform (1.04) fibres were produced from PVP03 sample produced with sodium persulfate.

While average fibre diameter of pure PAA nanofibres was calculated as $345.38 \mathrm{~nm}$, it increased to 484.76 $\mathrm{nm}$ with $\mathrm{WL}$ and $506.88 \mathrm{~nm}$ with glutaraldehyde addition. The most uniform (1.027) fibres were obtained from PAA01 sample (table 3 ). The presence of cross-linker into the polymer solution effects fibre morphology slightly as reported in the literature [18]. All the results of solution and fibre properties of PVP and PAA samples were given in table 3 .

\begin{tabular}{|c|c|c|c|c|c|c|c|}
\hline \multicolumn{8}{|c|}{ RESULTS OF SOLUTION AND FIBRE PROPERTIES OF PVP AND PAA SAMPLES } \\
\hline Sample & $\begin{array}{c}\text { Conductivity } \\
(\mu \mathrm{s} / \mathrm{cm})\end{array}$ & $\begin{array}{l}\text { Viscosity } \\
\text { (mPa.s) } \\
\left(5 \mathrm{~s}^{-1}\right)\end{array}$ & $\begin{array}{l}\text { Surface } \\
\text { tension } \\
(\mathrm{mN} / \mathrm{m})\end{array}$ & $\begin{array}{c}\text { Number average } \\
\text { diameter } A_{n} \\
(n m)\end{array}$ & $\begin{array}{l}\text { Weight average } \\
\text { diameter } A_{w} \\
(n m)\end{array}$ & $\begin{array}{l}\text { Fibre diameter } \\
\text { uniformity } \\
\text { coefficient } A_{w} / A_{n}\end{array}$ & $\begin{array}{l}\text { Standard } \\
\text { deviation }\end{array}$ \\
\hline PVP01 & 4.6 & 225 & 21.9 & 353.6 & 460.3 & 1.3 & 195.3 \\
\hline PVP02 & 34.7 & 305 & 18.4 & 431.1 & 491.7 & 1.1 & 162.5 \\
\hline PVP03 & 292.0 & 354 & 20.2 & 492.0 & 512.2 & 1.0 & 100.3 \\
\hline PAA01 & 0.6 & 84 & 21.8 & 345.4 & 354.8 & 1.0 & 57.3 \\
\hline PAA02 & 7.1 & 156 & 20.4 & 484.8 & 522.5 & 1.1 & 135.9 \\
\hline PAA03 & 12.8 & 183 & 20.7 & 506.9 & 539.1 & 1.1 & 128.5 \\
\hline
\end{tabular}



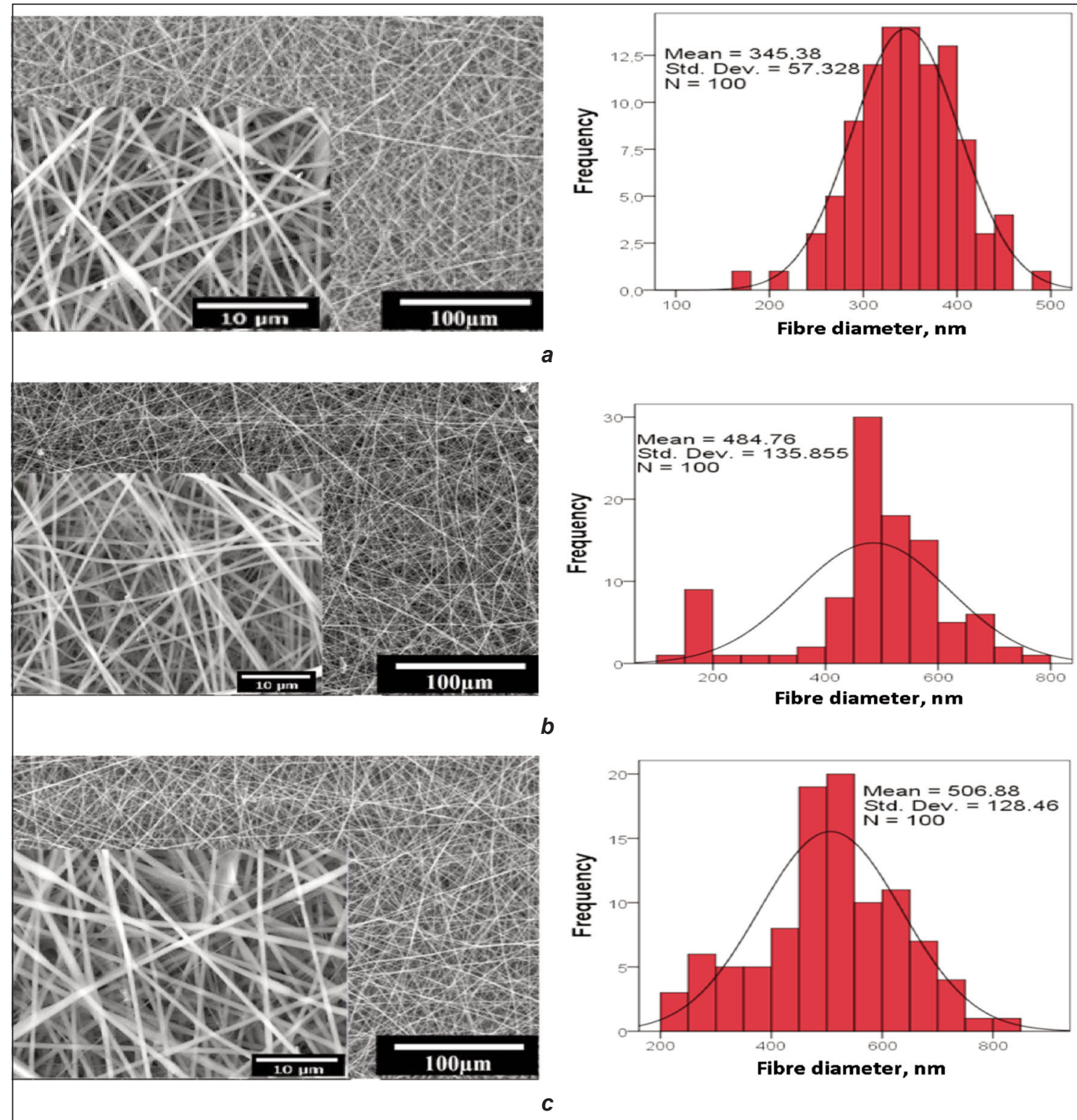

b

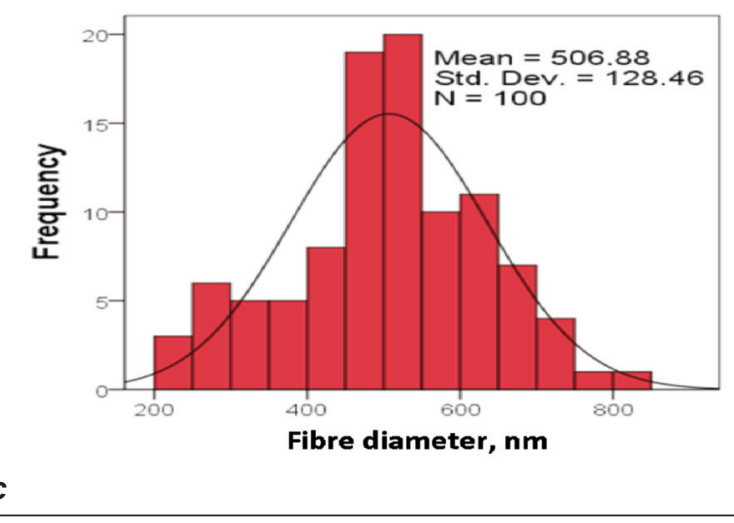

Fig. 3. SEM images $(1.000 \times-10.000 \times)$ and histograms of PAA nanofibre samples: a - PAA01; $b$ - PAA02; $c$ - PAA03

Table 4

\begin{tabular}{|c|c|c|}
\hline \multicolumn{3}{|c|}{$\begin{array}{c}\text { THICKNESS AND WEIGHT IN GRAMS VALUES } \\
\text { OF ELECTROSPUN PVP AND PAA NANOFIBRES }\end{array}$} \\
\hline Sample codes & $\begin{array}{c}\text { Thickness } \\
(\mathbf{m m})\end{array}$ & $\begin{array}{c}\text { Grammage } \\
\left(\mathbf{g} / \mathbf{m}^{2}\right)\end{array}$ \\
\hline PVP01 & 0.09 & 22.10 \\
\hline PVP02 & 0.14 & 37.90 \\
\hline PVP03 & 0.13 & 39.60 \\
\hline PAA01 & 0.08 & 22.00 \\
\hline PAA02 & 0.07 & 29.50 \\
\hline PAA03 & 0.07 & 32.20 \\
\hline
\end{tabular}

Thickness and weight in grams measurement results of electrospun PVP and PAA nanofibres are given in table 4.

According to the results of table 4, thickness and weight in grams of nanofibres values were compatible with each other. Weight in grams of nanoweb increases with WL and cross-linker addition while thickness was not change noticeably.

The absorption capacity of the produced cross-linked PVP and PAA nanofibres was tested with both water and synthetic urine for various times and results were given in figure 5 .

According to the figure 5, a, PVP nanoweb structure exhibited absorption from 560 to $1363 \%$ while PAA nanoweb structure has absorption from 599 to $2876 \%$ in water. Therefore, absorption capacity of PVP and PAA nanofibres increases with time, while PAA nanofibres absorption capacity is noticeably higher than PVP especially for 86400 seconds (24 hours). In water absorption tests, PAA nanofibres reached $50 \%$ of the absorption capacity in the first 1800 seconds (30 minutes) and reached maximum water absorption capacity in 86400 seconds (24 hours). On the other hand, PVP nanofibres reached approximately $90 \%$ of their absorption capacity in the first 1800 seconds (30 minutes). In addition, it is possible to say that PVP 


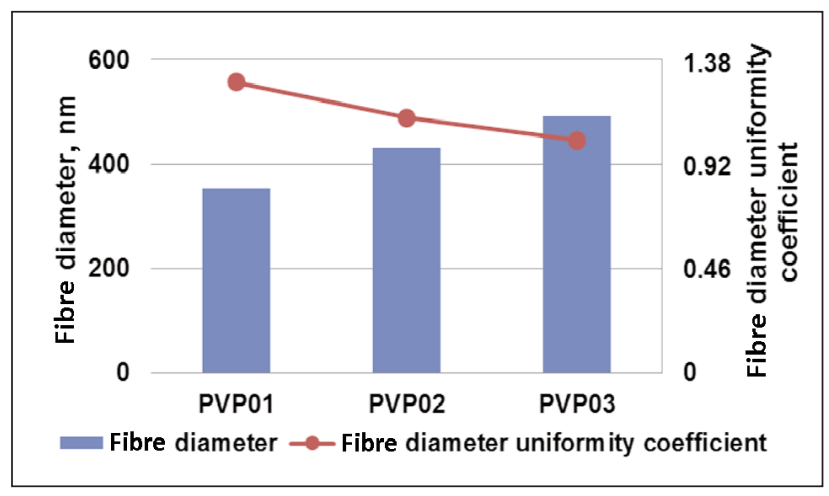

a

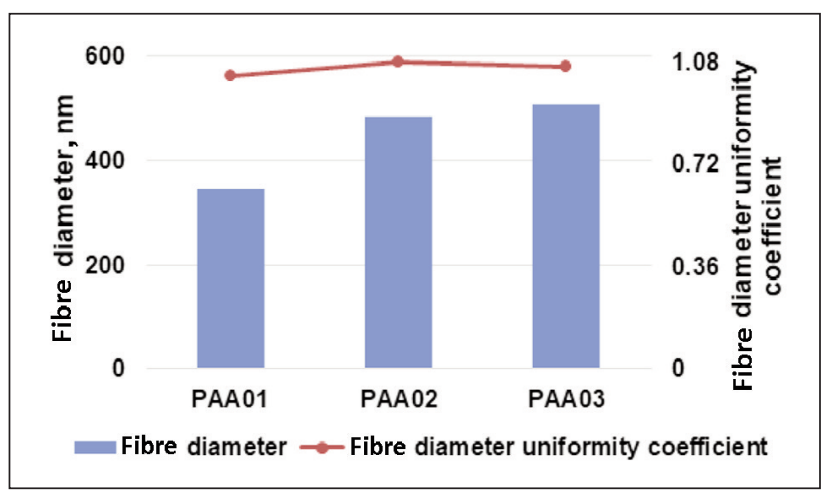

$\boldsymbol{b}$

Fig. 4. Average fibre diameter and diameter uniformity coefficient results of PVP and PAA nanofibres

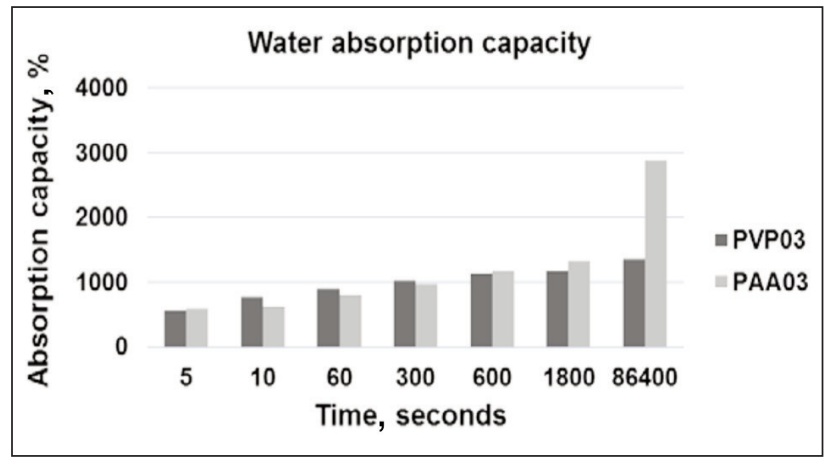

a

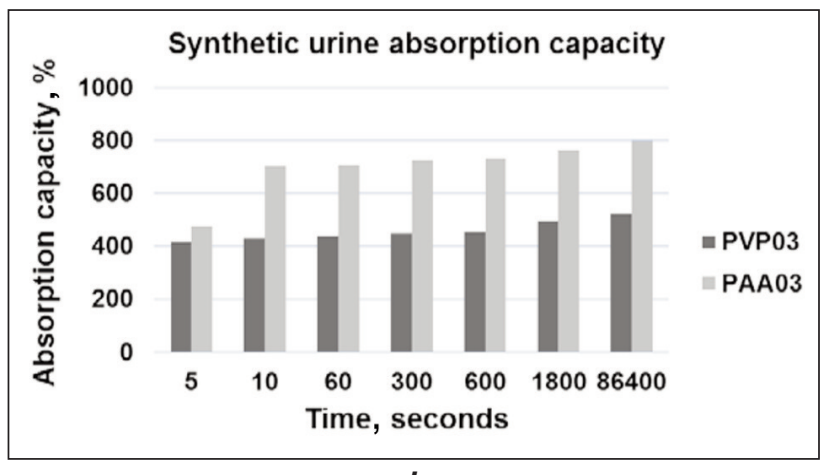

b

Fig. 5. Absorption capacity of electrospun PVP and PAA nanofibres for: $a$ - water; $b$ - synthetic urine

nanofibres absorption rate is higher than PAA. It was also specified in the literature that high surface area to volume ratio and porous structure of the nanofibre surfaces result in higher absorption capacity [19]. According to the figure 5, $b$ results, PVP nanoweb structure showed absorption from $416 \%$ to $523 \%$ in synthetic urine, and absorption from 477 to $797 \%$ for PAA nanofibres. It was obviously seen that PAA nanofibres' absorption percentage increases significantly at 10 seconds. After then absorption values increase slightly between 10 and 86400 seconds. Moreover, absorption values of PVP nanofibres increase slightly between 5 and 86400 seconds. In general, absorption capacity of PAA nanofibres of synthetic urine is higher than PVP. It was also observed that PVP and PAA nanofibres absorption capacity of water is higher than synthetic urine. This result is compatible with literature [13].

\section{CONCLUSIONS}

In the present study, superabsorbent nanofibrous surfaces with PVP and PAA were produced by electrospinning and absorption capacity of water and synthetic urine with various times was analysed. This study contributes to the literature concerning the comparative analyses of absorption capacity of PVP and PAA nanofibres.
According to the results, solution conductivity, viscosity and average fibre diameter increased with WL and cross-linker addition while surface tension was not change for both PVP and PAA. In general, fine, smooth and uniform nanofibres were determined. The water absorption test results showed that PAA nanofibres reached $50 \%$ of the absorption capacity while PVP nanofibres reached $90 \%$ of the absorption capacity in the first 30 minutes. It is possible to say, PVP nanofibres absorption rate is higher than PAA. On the other hand, it is concluded that PAA nanofibres have higher water and synthetic urine absorption capacity than PVP nanofibres. The authors expect that polymer based superabsorbent nanofibrous materials which are ultra-thin, light, porous, with high specific surface area to volume ratio were developed in this study will have a significant application potential for biomedical and hygienic textiles such as sanitary napkin and diaper.

\section{ACKNOWLEDGEMENTS}

The authors would like to thank Süleyman Demirel University Scientific Researches Project Unit (Project No: 4890-YL2-17) for financial support and Dr. Çiğdem AKDUMAN, Hülya KESici GÜLER and Açık Kart Technologies and Payment Systems Industry and Commerce Inc. (HIFYBER HIGH PERFORMANCE NANOFIBRES) for their contributions. 


\section{REFERENCES}

[1] Martinova, L., Lubasova, D., Nanofiber Sheets with the Superabsorbent Properties, In: Advanced Materials Research, 2012, 354, 210-215, https://doi.org/10.4028/www.scientific.net/AMR.354-355.210

[2] Karimi, A., Abbasi, M., Mokhtari, J., Electrospinning Superabsorbent Nanofiber Production Using Beta-Glucan, In: American Journal of Oil and Chemical Technologies, 2014, 2, 5, 45-47

[3] Islam, M.S., Rahaman, M.S., Yeum, J.H., Electrospun Novel Super-Absorbent Based on Polysaccharide-Polyvinyl alcohol-Montmorillonite Clay Nanocomposites, In: Carbohydrate Polymers, 2015, 115, 69-77, https://doi.org/ 10.1016/j.carbpol.2014.08.086

[4] Yoshimura, T., Matsunaga, M., Fujioka, R., Alginate-based Superabsorbent Hydrogels Composed of Carboxylic Acid-Amine Interaction: Preparation and Characterization, In: e-Polymers, 2009, 9, 1, 1-8, https://doi.org/ 10.1515/epoly.2009.9.1.968

[5] Chiţanu, E., Băra, A., Banciu, C., Lungulescu, M., Marinescu, V., Study of Electrospun Cellulose Acetate Fibers, In: Industria Textila, 2018, 69, 5, 363-368, https://doi.org/10.35530/IT.069.05.1511

[6] Lalani, R., Liu, L., Electrospun Zwitterionic Poly(sulfobetaine methacrylate) for Nonadherent, Superabsorbent and Antimicrobial Wound Dressing Applications, In: Biomacromolecules, 2012, 13, 6, 1853-1863, https://doi.org/ $10.1021 / \mathrm{bm} 300345 \mathrm{e}$

[7] Hwang, S., Yoon, W., Yun, S., Yoo, E., Kim, T., Im, S., Fabrication of Superabsorbent Ultrathin Nanofibers using Mesoporous Materials for Antimicrobial Drug-Delivery Applications, In: Macromolecular Research, 2013, 21, 11, 1281-1288, https://doi.org/10.1007/s13233-013-1178-3

[8] Subtirica, A.I., Banciu, C.A., Chivu, A.A.M., Dinca, L.C., Nanofibres Made from Biocompatible and Biodegradable Polymers, with Potential Application as Medical Textiles, In: Industria Textila, 2018, 69, 1, 55-58, https://doi.org/10.35530/IT.069.01.1502

[9] Lubasova, D., Niu, H., Zhao, X., Lin, T., Hydrogel Properties of Electrospun Polyvinylpyrrolidone and Polyvinylpyrroline/Poly(acrylic acid) Blend Nanofibers, In: RSC Advances, 2015, 5, 67, 54481-54487, https://doi.org/10.1039/C5RA07514A

[10] Dai, M., Jin, S., Nugen, S.R., Water-Soluble Electrospun Nanofibers as a Method for On-Chip Reagent Storage, In: Biosensors, 2012, 2, 4, 388-395, https://doi.org/10.3390/bios2040388

[11] Santiago-Morales, J., Amariei, G., Letón, P., Rosal, R., Antimicrobial Activity of Poly(vinyl alcohol)-poly(acrylic acid) Electrospun Nanofibers, In: Colloids and Surfaces B: Biointerfaces, 2016, 146, 144-151, https://doi.org/ 10.1016/j.colsurfb.2016.04.052

[12] Li, L., Hsieh, Y., Ultra-fine Polyelectrode Hydrogel Fibres from Poly(acrylic acid)/Poly(vinyl alcohol), In: Nanotechnology, 2005, 16, 12, 2852-2860, https://doi.org/10.1088/0957-4484/16/12/020

[13] Hansen, L., Smith, D., Renekel, D., Kataphinan, W., Water Absorption and Mechanical Properties of Electrospun Structured Hydrogels, In: Journal of Applied Polymer Science, 2005, 95, 2, 427-434, https://doi.org/ 10.1002/app.21117

[14] Ranjbari, E., Bazgir, S., Shirazi, M. M. A., Needleless Electrospinning of Poly (acrylic acid) Superabsorbent: Fabrication, Characterization and Swelling Behavior, In: Polymer Testing, 2020, 84, 106403, https://doi.org/ 10.1016/j.polymertesting.2020.106403

[15] Aminyan, R., Bazgir, S., Fabrication and Characterization of Nanofibrous Polyacrylic Acid Superabsorbent using Gas-Assisted Electrospinning Technique, In: Reactive and Functional Polymers, 2019, 141, 133-144, https://doi.org/10.1016/j.reactfunctpolym.2019.05.012

[16] Li, Z., Wang, C., Effects of Working Parameters on Electrospinning, In: One-Dimensional Nanostructures, 2013, 15-28, https://doi.org/10.1007/978-3-642-36427-3_2

[17] Cengiz, F., Jirsak, O., The Effect of Salt on the Roller Electrospinning of Polyurethane Nanofibers, In: Fibers and Polymers, 2009, 10, 2, 177-184, https://doi.org/10.1007/s12221-009-0177-7

[18] Fang, J., Lin, T., Tian, W., Sharma, A., Wang, X., Toughened Electrospun Nanofibers from Crosslinked ElastomerThermoplastic Blends, In: Journal of Applied Polymer Science, 2007, 105, 4, 2321-2326, https://doi.org/ 10.1002/app.26422

[19] Babaeijandaghi, F., Shabani, I., Seyedjafari, E., Naraghi, Z.S., Vasei, M., Haddadi-Asl, V., Soleimani, M., Accelerated Epidermal Regeneration and Improved Dermal Reconstruction Achieved by Polyethersulfone Nanofibers, In: Tissue Engineering Part A, 2010, 16, 11, 3527-3536, https://doi.org/10.1089/ten.tea.2009.0829.

\section{Authors: \\ BUKET GÜLER, FUNDA CENGIZ ÇALLIOĞLU}

Süleyman Demirel University, Engineering Faculty, Textile Engineering Department, 32260, Çünür, Isparta, Turkey e-mail: buketguler58@gmail.com

\section{Corresponding author:}

FUNDA CENGIZ ÇALLIOĞLU

e-mail: fundacengiz@sdu.edu.tr 